\title{
The presence of Helicobacter pylori in the liver depends on the Th1, Th17 and Treg cytokine profile of the patient
}

\author{
Luciana Diniz Silva', Andreia Maria Camargos Rocha', Gifone Aguiar Rocha', \\ Sílvia Beleza de Moura², Márcia Maria Negreiros Pinto Rocha', Renato Dani ${ }^{3}$, \\ Fabrício Freire de Melo ${ }^{1,2}$, Juliana Becattini Guerra', Lúcia Porto Fonseca de Castro4, \\ Guilherme Santiago Mendes ${ }^{3}$, Teresa Cristina de Abreu Ferrari ${ }^{5}$, \\ Agnaldo Soares Lima ${ }^{5}$, Dulciene Maria Magalhães Queiroz ${ }^{1 /+}$
}

\footnotetext{
${ }^{1}$ Laboratório de Pesquisa em Bacteriologia ${ }^{4}$ Departamento de Anatomia Patológica ${ }^{5}$ Serviço de Transplante, Hospital das Clínicas, Faculdade de Medicina ²Departamento de Microbiologia, Instituto de Ciências Biológicas, Universidade Federal de Minas Gerais, Belo Horizonte, MG, Brasil ${ }^{3}$ Hospital Governador Israel Pinheiro, Instituto de Previdência dos Servidores do Estado de Minas Gerais, Belo Horizonte, MG, Brasil
}

The hypothesis that Helicobacter might be a risk factor for human liver diseases has arisen after the detection of Helicobacter DNA in hepatic tissue of patients with hepatobiliary diseases. Nevertheless, no explanation that justifies the presence of the bacterium in the human liver has been proposed. We evaluated the presence of Helicobacter in the liver of patients with hepatic diseases of different aetiologies. We prospectively evaluated 147 patients (106 with primary hepatic diseases and 41 with hepatic metastatic tumours) and 20 liver donors as controls. Helicobacter species were investigated in the liver by culture and specific $16 \mathrm{~S} r \mathrm{DNA}$ nested-polymerase chain reaction followed by sequencing. Serum and hepatic levels of representative cytokines of T regulatory cell, Thelper (Th)1 and Th17 cell lineages were determined using enzyme linked immunosorbent assay. The data were evaluated using logistic models. Detection of Helicobacter pylori DNA in the liver was independently associated with hepatitis B virus/ hepatitis $C$ virus, pancreatic carcinoma and a cytokine pattern characterised by high interleukin (IL)-10, low/absent interferon- $\gamma$ and decreased IL-17A concentrations $\left(p<10^{-3}\right)$. The bacterial DNA was never detected in the liver of patients with alcoholic cirrhosis and autoimmune hepatitis that are associated with Th1/Th17 polarisation. H. pylori may be observed in the liver of patients with certain hepatic and pancreatic diseases, but this might depend on the patient cytokine profile.

Key words: Helicobacter pylori - liver diseases - IL-10 - IL-17 - IFN- $\gamma$

The hypothesis that Helicobacter spp might be a risk factor for human liver diseases has arisen after the discovery of Helicobacter hepaticus and its association with murine hepatitis and hepatocellular carcinoma (HCC). Subsequent studies in humans have shown the presence of Helicobacter DNA in hepatic tissue of patients with hepatobiliary diseases, mainly cirrhosis and/ or HCC secondary to hepatitis B virus (HBV) and hepatitis C virus (HCV) (Avenaud et al. 2000, Dore et al. 2002, Fan et al. 2002, Verhoef et al. 2003, Rocha et al. 2005, Pellicano et al. 2008). Although these studies have contributed to the debate on the participation of Helicobacter species in the severe human liver disease outcomes, no explanation that justifies the presence of the bacterium in the human liver has yet been proposed.

\footnotetext{
Financial support: CNPq, FAPEMIG, CAPES, Sixth Framework Program of the European Union (Project CONTENT; INCO-CT-2006032136) (to DMMQ)

+ Corresponding author: dqueiroz@medicina.ufmg.br

Received 23 March 2011

Accepted 9 August 2011
}

We isolated for the first time a strain of Helicobacter pylori from the liver of a patient with Wilson's disease, who had developed fulminant hepatitis after surgery (Queiroz et al. 2001). Along with the intrinsic relevance of finding viable $H$. pylori in the human liver, this result provided a new perspective that Helicobacter can be present in the liver of patients with hepatic disorders distinct from those already investigated. This finding motivated us to search for Helicobacter spp in the liver of consecutive patients submitted to hepatic biopsy for diagnosis and/or to determine the stage of their hepatic diseases.

Since we found $H$. pylori DNA in the liver of patients with a variety of liver diseases, we aimed to investigate what these patients share that might explain the presence of the bacterium in their livers. Because the host immune response is crucial in the control of pathogens, we evaluated serum and hepatic levels of representative cytokines of T regulatory cell (Treg) [interleukin (IL)-10], T helper (Th)1 [interferon (IFN)- $\gamma$ ] and Th17 (IL-17A) cell populations. IL-10 can suppress the immune response against pathogens, including those of the genus Helicobacter (Algood \& Cover 2006), mainly by inhibiting IFN- $\gamma$. IFN- $\gamma$ is considered an essential molecule for the control of intracellular pathogens, but also acts against Helicobacter (D'Elios et al. 1997, Straubinger et al. 2003). The recently discovered pro-inflammatory Th17 cell and its 
major inflammatory cytokine, IL-17A, have the capacity to confer protection against extracellular bacteria, among them, H. pylori (Caruso et al. 2007). The evaluation of these cytokines is also justified due to their relevant participation in the hepatic disease pathogenesis. The balance between the Treg and Th1 responses to $\mathrm{HBV} / \mathrm{HCV}$ may determine the outcome of immunoprotection or immunopathology (Fainboim et al. 2007). Recent studies have suggested that IL-17A/Th17 cells might also participate in the immunopathogenesis of chronic HBV infection (Zhang et al. 2010) and alcoholic liver disease (Lemmers et al. 2009). Therefore, we evaluated the associations among the presence of Helicobacter in the liver, the aetiology and stage of the hepatic disease and the cytokine pattern displayed by the patients.

\section{PATIENTS, MATERIALS AND METHODS}

Patients - Between March 2000-December 2005, 147 subjects who had undergone liver biopsy for diagnosis or grading and staging of hepatic disease at Governador Israel Pinheiro Hospital and Júlia Kubitscheck Hospital, Belo Horizonte, state of Minas Gerais, Brazil, were prospectively and consecutively included in this study.

The diagnosis of the disease aetiology and stage was based on standard clinical, biochemical, serological, radiological and histological criteria (Sherlock \& Dooley 2002). Exclusion criteria included patients with human immunodeficiency virus or with concomitant hepatic diseases, patients in use or with previous use of anti-viral HBV/HCV treatment or immunosuppressive drugs.

Overall, 106 patients had the following hepatic diseases: alcoholic hepatic disease $(n=31)$, autoimmune chronic hepatitis $(\mathrm{n}=14), \operatorname{HCV}(\mathrm{n}=10)$, drug-induced liver disease $(n=11)$, cryptogenic cirrhosis $(n=7)$, HBV $(\mathrm{n}=10)$, non-alcoholic steatohepatitis $(\mathrm{n}=5)$, genetic/ congenital disorders [haemochromatosis $(\mathrm{n}=3)$, Wilson's disease $(\mathrm{n}=1)$ and Caroli's disease $(\mathrm{n}=2)$ ], parasitic/bacterium diseases [chronic mansonic schistosomiasis $(n=5)$, hepatic bacterium abscess $(n=1)$ and visceral leishmaniasis $(\mathrm{n}=1)$ ], primary sclerosing cholangitis (n $=3), \mathrm{HCC}$ without cirrhosis $(\mathrm{n}=1)$ and one patient with consistently increased gamma glutamyl transpeptidase levels. The isolation of $H$. pylori from the liver of the patient with Wilson's disease has already been reported in Queiroz et al. (2001); the patient was included in this study for the other analyses.

Forty one patients had metastatic tumours in the liver arising from the pancreas $(n=13)$, gallbladder $(n=6)$, stomach ( $(n=3)$, colon/rectum $(n=3)$, breast $(n=2)$, ovary $(n=2)$, oesophagus $(n=1)$, lung $(n=1)$, kidney $(n=1)$ and uterine cervix $(\mathrm{n}=1)$ or hepatic non-Hodgkin lymphoma $(\mathrm{n}=5)$ and neuroendocrine tumour $(\mathrm{n}=1)$. In two patients, the tumour primary site was not identified.

As a control group, we included the livers from 20 liver donors from the Transplant Service of the University Hospital of the Federal University of Minas Gerais who died due to head injury, cerebral haemorrhage or cerebral infarction.

Liver fragments for culture and DNA extraction were obtained from each patient by laparoscopical or percutaneous route using a Menghini needle and from the liver donors with a 16-gauge needle during the liver transplantation procedure. Clinical, epidemiologic and demographic data were collected using a questionnaire.

Aliquots of venous blood samples were stored at $-80^{\circ} \mathrm{C}$ for DNA extraction and cytokine evaluation and at $-20^{\circ} \mathrm{C}$ for serology.

Gastric H. pylori infection status - H. pylori infection status of the patients was evaluated with a ${ }^{13} \mathrm{C}$ urea breath test (UBT) and/or by a second-generation enzyme linked immunosorbent assay (ELISA) (Cobas Core, anti-H. pylori EIA, Roche, Switzerland) (Rocha et al. 1998). The patient was considered to have a gastric $H$. pylori-positive status when the ELISA and/or UBT were positive. The patients were H. pylori-negative when both tests were negative. In the case of the liver donors, the gastric status was determined using ELISA alone.

Detection of Helicobacter in the liver fragments - For Helicobacter isolation, liver fragments were ground in $0.5 \mathrm{~mL}$ brain heart infusion (Difco Laboratories, Detroit, $\mathrm{MI}$ ) in a glass tissue grinder, inoculated onto plates containing Belo Horizonte medium (BHM) prepared the same day of the inoculum and incubated under microaerophilic atmosphere (Anaerocult C, Merck, Darmstadt, Germany) at $37^{\circ} \mathrm{C}$. Plates were checked every three days. Brucella broth was added to the agar surface to ensure that the plates would not dry out. If no bacterial growth was observed after 10 days of incubation, the plates were scraped and the material transferred to a new fresh BHM, checking every three days for 21 days. After this period, if no growth was observed, the plates were discharged.

The isolates were phenotypically identified as previously described (Queiroz et al. 2001). For genotypic characterisation, bacterial DNA was extracted with the QIAamp DNA Mini kit (Qiagen GmbH, Hilden, Germany) (Oliveira et al. 2006). The $16 \mathrm{~S}$ rRNA gene ( 1,500 bp) was amplified and the products were sequenced as previously described (Queiroz et al. 2001).

For Helicobacter DNA detection, liver tissue DNA was extracted with a QIAamp DNA Mini kit and the 16S rRNA gene was amplified by nested polymerase chain reaction (PCR) for the Helicobacter genus (Oliveira et al. 2006). A nested PCR specific for H. pylori ureA was also employed (Wang et al. 1993). An Escherichia coli strain (clinical isolate) and a H. pylori strain (TX30A) were used as negative and positive controls, respectively, and distilled water was used as an internal reaction negative control. PCR that targets the beta-globulin gene was used for testing residual inhibitors (Oliveira et al. 2006). The PCR products of $400 \mathrm{bp}$ were purified and directly sequenced as previously described (Queiroz et al. 2001). A 16S rRNA gene nested PCR was also performed on DNA extracted from blood samples.

H. pylori was also investigated by an indirect labelling streptavidin-biotin immunohistochemistry (Marzio et al. 1998) using a rabbit anti-H. pylori-specific antibody (Dako, Hamburg, Germany) on hepatic fragments from patients who were positive or negative for $H$. pylori DNA in the liver (10 in each group). Gastric mucosa sections from $H$. pylori-positive and negative patients were included as positive and negative controls, respectively. 
Serum and liver cytokine concentrations - The cytokine levels in the serum (available from all subjects) and in the supernatant of hepatic tissue samples (available from 85 subjects) were assayed in duplicate using ELISA (Biosource, Camarillo, CA) (Moura et al. 2008). The hepatic levels were expressed as picograms of cytokine per milligram of tissue protein ( $\mathrm{pg} / \mathrm{mg}$ protein) and serum levels as picograms per millilitre $(\mathrm{pg} / \mathrm{mL})$. The minimum detectable level was $1.0 \mathrm{pg} / \mathrm{mL}$ of IL-10, $2.0 \mathrm{pg} / \mathrm{mL}$ of IL-17A and $4.0 \mathrm{pg} / \mathrm{mL}$ of IFN- $\gamma$. An ultrasensitive test was used for assessing undetectable levels of IL-10 $(0.2 \mathrm{pg} / \mathrm{mL})$ in the conventional assay. All values below the detection levels were regarded as undetectable and were ascribed the value zero.

Data were analysed with SPSS (SPSS Inc, Chicago, IL) statistical software package version 17.0. Associations between the presence of $H$. pylori DNA in the liver and hepatic diseases, gastric $H$. pylori status, cytokine levels, gender and age were evaluated by univariate analysis. All the variables with $\mathrm{p} \leq 0.20$ were included in the full models of logistic regression. Odds ratio and $95 \%$ confidence interval were used as an estimate of the risk. In addition to the visual examination of histograms and box plots, the Kolmogorov-Smirnov goodness-of-fit test was used to assess the normality of cytokine concentrations. Significant departures from normality were detected for all cytokines. After log transformation, because none of the cytokines became normally distributed $(p>0.20)$, all the comparisons were analysed using the Mann Whitney U test. The correlations were evaluated with Pearson's correlation test. The level of significance was set at $\mathrm{p}<0.05$.

Ethics - This study was approved by the ethical committee of the involved institutions. Informed consent to participate was obtained from all patients and, in the case of the liver donors, from the first relative of the deceased donor.

\section{RESULTS}

The characteristics of the subjects are shown in the Table I. In regard to the gastric H. pylori status, $78.9 \%$ of the patients and $55 \%$ of the liver donors were H. pylori-positive.

Bacterial culture - In addition to the isolation of $H$. pylori from the liver of the patient with Wilson's disease that was complicated with fulminant hepatitis after surgery (Queiroz et al. 2001), Helicobacter suspected colonies were observed on the plates inoculated with liver fragments from two other patients $(1$ with chronic $\mathrm{HCV}$ and the other with alcoholic acute hepatitis) after six and 21 days of incubation, respectively. According to the phenotypic characteristics, both isolates were identified as $H$. pylori. The bacteria were motile, nonspore-forming, slightly curved, Gram-negative bacilli that produced urease, catalase, oxidase, alkaline phosphatase and $\gamma$-glutamyl transpeptidase. They did not reduce nitrate to nitrite, did not hydrolyse hippurate and did not produce hydrogen sulphide. The bacteria grew microaerobically at $37^{\circ} \mathrm{C}$, but not at $25^{\circ} \mathrm{C}$ or $42^{\circ} \mathrm{C}$. No growth was observed under aerobic or anaerobic condi- tions. The bacteria did not grow in $1 \%$ of glycine, $1 \%$ Ox bile or $1.5 \% \mathrm{NaCl}$. The strains were resistant to nalidixic acid and sensitive to cephalotin.

The isolates were also genotypically identified as $H$. pylori based on the sequencing of more than $95 \%$ of the $1,500 \mathrm{bp}$ amplicon from each of them, which showed more than $99 \%$ similarity to $16 \mathrm{~S}$ rRNA gene of $H$. pylori (GenBank accessions EU035396 and EU033951).

H. pylori-specific immunohistochemistry confirmed the presence of $H$. pylori in the liver from these patients (Fig. 1), whereas no spiral bacteria were found in the liver of the other patients.

Two of the three patients agreed to undergo gastroduodenoscopy to evaluate the gastric Helicobacter status. In the patient with acute alcohol disease, gastric and hepatic $H$. pylori strains were cagA-negative and vacA $\mathrm{s} 2 \mathrm{~m} 2$. In the patient with Wilson's disease, two types of H. pylori strains were isolated from the stomach (1 was cagA-positive and vacA s1m1 and the other was cagAnegative and $v a c \mathrm{~A} s 2 \mathrm{~m} 2$ ), meanwhile, only cagA-negative, $v a c \mathrm{~A} \mathrm{~s} 2 \mathrm{~m} 2$ colonies were isolated from the liver. The strain isolated from the liver of the third patient was also characterised as cagA-negative and vacA s $2 \mathrm{~m} 2$.

Helicobacter DNA detection - Helicobacter DNA was detected by amplification of $16 \mathrm{~S}$ rDNA in 58/167 (34.7\%) liver samples (Table I). In all positive cases, $16 \mathrm{~S}$ rDNA (400 bp) and ureA (361 bp) amplicons were obtained. Forty-eight $(82.8 \%)$ of the 400 bp amplicons were sequenced and all were found to be more than $99 \%$ similar to the 16S rRNA gene of H. pylori (GenBank accessions EU008827, EU018205, EU018206, EU020081 to EU020083, EU024522 to EU024528, EU029065 to EU029073, EU033933 to EU033950, EU072993, EU072994, EU106634, EU106635 and EU110052).

H. pylori DNA was more frequently detected in the liver of patients with liver diseases than in controls $(p=$ 0.01 ), as well as in the metastatic tumour patients than in the controls $(\mathrm{p}=0.01)$.

There was a high frequency of $H$. pylori DNA detection in the liver of patients with pancreatic tumours (11 of 16 tumour-positive cases) compared with controls. The difference was significant, even after adjustment for age, gender and H. pylori positive serology/UBT $(\mathrm{p}=$ 0.002). Helicobacter DNA was not detected in the peripheral blood of any subject.

Table II shows the distribution of the patients according to the aetiology and stage of the hepatic disease and hepatic H. pylori DNA status. In the group of patients with primary liver disease, positive DNA samples were mainly observed in all stages of $\mathrm{HBV} / \mathrm{HCV}$ and in noncirrhotic alcoholic disease. Otherwise, $H$. pylori DNA was never detected in the liver of patients with cirrhosis/HCC due to alcoholic disease or patients with autoimmune hepatitis.

IL-10, IL-17A and IFN- $\gamma$ concentrations - IL-10 and IL-17A levels were detected in the serum of all patients and controls as well as in the liver samples, whereas IFN- $\gamma$ was detected only in $65.6 \%$ of serum samples and in $25.9 \%$ of liver fragments.

Significant and high correlations $\left(\mathrm{p}<10^{-3}\right)$ were seen between serum and liver levels of IL-10 $(\mathrm{r}=0.85)$, IL-17A $(r=0.92)$ and IFN- $\gamma(r=0.77)$, which indicated 
TABLE I

Demographic characteristics of the subjects and Helicobacter pylori DNA detection in the liver

\begin{tabular}{lccccc}
\hline Subjects & $\begin{array}{c}\text { Total } \\
(\mathrm{n})\end{array}$ & $\begin{array}{c}\text { Gender } \\
(\mathrm{M} / \mathrm{F})\end{array}$ & $\begin{array}{c}\text { Mean age + SD } \\
\text { (years) }\end{array}$ & $\begin{array}{c}\text { Age range } \\
\text { (years) }\end{array}$ & $\begin{array}{c}\text { H. pylori DNA in the liver } \\
\mathrm{n}(\%)\end{array}$ \\
\hline Patients with hepatic disease & 106 & $58 / 48$ & $49.6 \pm 15.2$ & $18-87$ & $41(38.7)$ \\
Patients with hepatic metastasis & 41 & $16 / 25$ & $57.9 \pm 14.9$ & $30-93$ & $16(39)$ \\
Liver donors & 20 & $14 / 6$ & $32.9 \pm 13.4$ & $18-62$ & $1(5)$ \\
\hline Total & 167 & $88 / 79$ & $49.6 \pm 16.4$ & $18-93$ & $58(34.7)$ \\
\hline
\end{tabular}

F: female; M: male; n: number of subjects; SD: standard deviation.

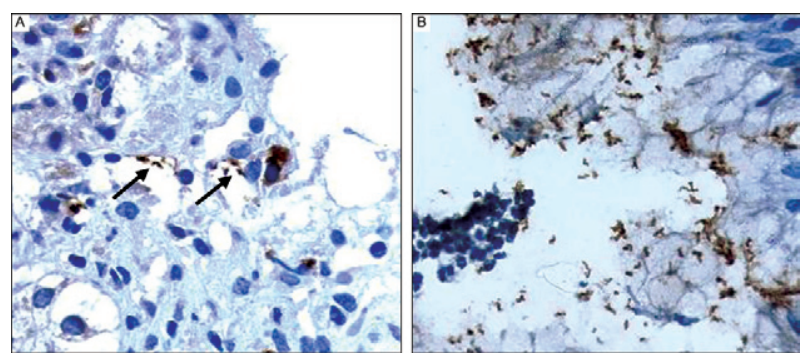

Fig. 1: immunohistochemical staining with anti-Helicobacter pylori specific antibodies showing brown-staining spiral bacteria (arrows) in the hepatic parenchyma of a patient with Wilson's disease complicated with fulminant hepatitis (A) and in the control gastric mucosa (B) (original magnification 1,000X).

that the serum mirrors the liver cytokine levels. Additionally, serum samples were available in all cases. The serum cytokine levels, instead of liver cytokine concentrations, were chosen as a co-variable to be included in the logistic analyses.

Cytokine levels according to the presence of $H$. pylori DNA in the liver - The median serum level of IL-10 (15.9 pg/mL, range 9.0-22.0) was higher, whereas IL-17A (146.0 pg/mL, range 30.0-196.0) and IFN- $\gamma(0 \mathrm{pg} / \mathrm{mL}$, range $0.0-23.0$ ) was lower in the patients with $H$. pylori DNA in the liver compared to those without it $(9.2 \mathrm{pg} /$ $\mathrm{mL}$, range $0.0-33.0 ; 298.0 \mathrm{pg} / \mathrm{mL}$, range $21.0-595.0$ and $9.8 \mathrm{pg} / \mathrm{mL}$, range $0.0-71.0$, respectively) $\left(\mathrm{p}<10^{-3}\right.$ for all).

The results were reproduced when the tissue levels were evaluated such that the IL-10 median concentration was higher $\left(\mathrm{p}<10^{-3}\right)$ in the patients with $(460.0 \mathrm{pg} / \mathrm{mg}$, range 198.0-761.0) than in those without $(98.3 \mathrm{pg} / \mathrm{mg}$, range 6.0-821.0) $H$. pylori DNA in the liver. Meanwhile, the mean level of IL-17A was lower in the patients with (718.0 pg/mg, range 87.0-744.0) than in those without (860.0 pg/mg, range $90.0-1510.0) H$. pylori DNA in the liver $\left(\mathrm{p}<10^{-3}\right)$. IFN- $\gamma$ levels were never detected in livers positive for the presence of $H$. pylori DNA $(\mathrm{p}=0.02)$.

Cytokine levels according to the hepatic disease - Fig. 2 shows the serum and hepatic cytokine levels according to the hepatic diseases. The cytokine profile, characterised by increased IL-10 levels and decreased IL-17A and IFN- $\gamma$ levels, was very similar among $\mathrm{HBV} / \mathrm{HCV}$, noncirrhotic alcoholic disease and pancreatic carcinoma groups. On the other hand, an almost opposite cytokine profile, characterised by decreased IL-10 levels and increased IL-17A and IFN- $\gamma$ levels, was observed in both alcoholic cirrhosis and autoimmune hepatitis groups.

Variables associated with the presence of $H$. pylori $D N A$ in the liver - Because the presence of $H$. pylori was more frequently observed in the patients with HBV/ $\mathrm{HCV}$, noncirrhotic alcoholic disease and pancreatic carcinoma, we included these variables together in the logistic models. In the univariate analysis, positive $H$. pylori UBT/serology, HBV/HCV/noncirrhotic alcoholic disease/pancreatic tumour and the cytokine levels were selected and remained independently associated with the presence of $H$. pylori DNA in the liver in the multivariate analyses (Table III).

The presence of cirrhosis in the group of patients with hepatic diseases $(\mathrm{n}=53-50 \%)$ did not associate $(\mathrm{p}$ $=0.11)$ with the presence of $\mathrm{H}$. pylori in the liver $(37 \mathrm{H}$. pylori-negative and 16 positive).

\section{DISCUSSION}

Only $H$. pylori strains were grown, and $H$. pylori DNA was detected in the hepatic tissue of the population studied, although the methods employed allow the growth and/or detection of other Helicobacter species, including those already described in human and animal livers (Pellicano et al. 2008). Positive liver culture and histology in only $1.8 \%$ of the all included individuals indicate that, in most cases, the bacterial load in the liver may be too low to be detected by these methods and/or that the presence of viable $H$. pylori in the liver is not common.

H. pylori DNA, however, was detected in $34.7 \%$ of the livers, mainly in patients with alcoholic hepatitis without cirrhosis, $\mathrm{HBV} / \mathrm{HCV}$ and pancreatic carcinoma who shared a similar serum/hepatic cytokine profile that was characterised by high IL-10, low or absent IFN- $\gamma$ and decreased IL-17 levels. Otherwise, $H$. pylori DNA was not detected in the liver of patients with alcoholic cirrhosis and those with autoimmune hepatitis. In agreement with previous studies (Straubinger et al. 2003, Algood \& Cover 2006, Lafdil et al. 2010), we confirmed the strong Th1 proinflammatory response with increased levels of IFN- $\gamma$, the Th1 signature cytokine, in these patients. We 
TABLE II

Helicobacter pylori (HP) DNA in the liver according to the aetiology and the stage ${ }^{a}$ of the liver diseases of 106 patients

\begin{tabular}{|c|c|c|c|c|c|c|c|c|c|c|}
\hline \multirow[b]{3}{*}{ Hepatic disease } & \multicolumn{4}{|c|}{ Disease staging } & \multirow{2}{*}{\multicolumn{2}{|c|}{$\begin{array}{c}\text { Total } \\
\begin{array}{c}\text { Hepatocellular } \\
\text { carcinoma }\end{array}\end{array}$}} & \multirow[b]{3}{*}{ HP- } & \multirow[b]{3}{*}{$\%$} & \multirow[b]{3}{*}{$\mathrm{HP}+$} & \multirow[b]{3}{*}{$\%$} \\
\hline & \multicolumn{2}{|c|}{$\begin{array}{l}\text { Without } \\
\text { cirrhosis }\end{array}$} & \multicolumn{2}{|c|}{$\begin{array}{c}\text { With } \\
\text { cirrhosis }\end{array}$} & & & & & & \\
\hline & HP- & $\mathrm{HP}+$ & HP- & $\mathrm{HP}+$ & HP- & $\mathrm{HP}+$ & & & & \\
\hline Hepatitis B virus & 0 & 2 & 0 & 7 & 0 & 1 & 0 & 0 & 10 & 100 \\
\hline Hepatitis $\mathrm{C}$ virus & 2 & 3 & 0 & 4 & 0 & 1 & 2 & 20 & 8 & 80 \\
\hline Alcoholic hepatic disease & 1 & 5 & 22 & 0 & 3 & 0 & 26 & 83.9 & 5 & 16.1 \\
\hline Autoimmune hepatitis & 9 & 0 & 5 & 0 & 0 & 0 & 14 & 100 & 0 & 0 \\
\hline Miscellaneous $^{b}$ & 15 & 15 & 7 & 3 & 1 & 0 & 23 & 56.1 & 18 & 43.9 \\
\hline Total & 27 & 25 & 34 & 14 & 4 & 2 & 65 & 61.3 & 41 & 38.7 \\
\hline
\end{tabular}

$a$ : classification based on the most severe hepatic lesion; $b$ : genetic/congenital disorders, parasitic/bacterial diseases, non-alcoholic steatohepatitis, primary sclerosing cholangitis, crytogenetic cirrhosis, hepatocellular carcinoma without cirrhosis, hepatitis due to drug use/exposure (ampicillin sodium/sulbactam sodium, amoxicillin clavulanate, ciproflaxin, norfloxacin, ketoconazole, amphetamine) and one patient with consistently increased gamaglutamyl transpeptidase levels; -: negative; +: positive.
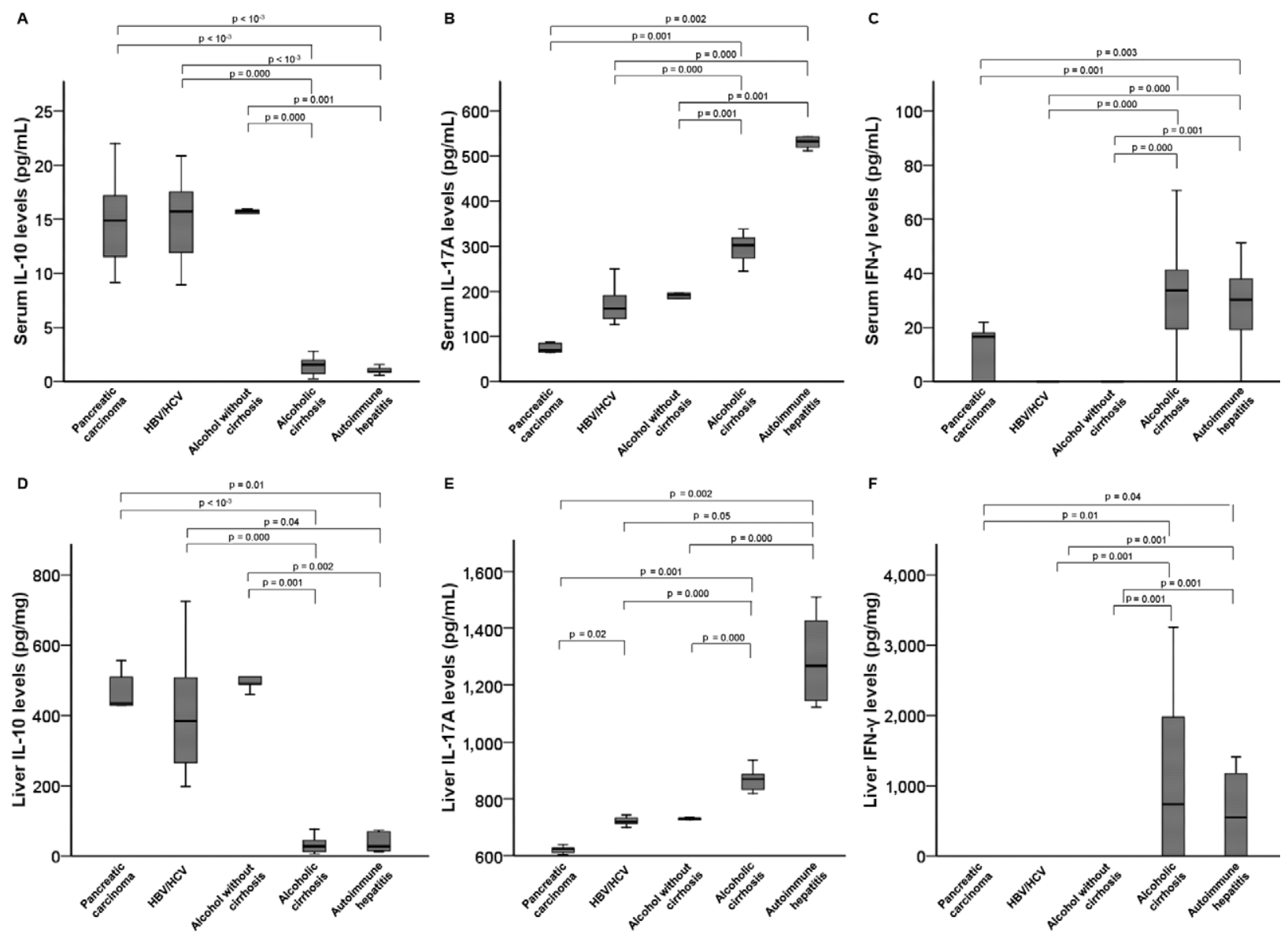

Fig. 2: serum levels of interleukin (IL)-10 (A), IL-17A (B) and interferon (IFN)- $\gamma$ (C) and hepatic levels of IL-10 (D), IL-17A (E) and IFN- $\gamma$ (F) according to the diseases. The serum and liver tissue cytokine levels were assayed in duplicate by enzyme linked immunosorbent assay (Biosource, Camarillo, CA). Each box shows the median (horizontal bar) and the lower and upper quartiles. Capped bars indicate the minimum and maximum values. Only significant $\mathrm{p}$ values are shown Helicobacter pylori DNA was found only in the liver of patients with alcoholic hepatitis without cirrhosis, hepatitis B virus (HBV)/hepatitis C virus (HCV) chronic infection and pancreatic carcinoma that have a cytokine profile characterized by increased serum and tissue levels of IL-10 and decreased levels of IL-17A and IFN- $\gamma$ (A, D). On the other hand, $H$. pylori DNA was not detected in the liver of patients with alcoholic cirrhosis and autoimmune hepatitis who have an opposite cytokine profile characterized by decreased serum and liver levels of IL-10 and increased serum and liver levels of IL-17A and IFN- $\gamma$ (B, C, E, F). 
TABLE III

Variables associated with the presence of Helicobacter pylori DNA in the liver

\begin{tabular}{|c|c|c|c|c|}
\hline \multirow[b]{2}{*}{ Variables } & \multirow{2}{*}{$\frac{\text { Univariate analysis }}{\mathrm{p}}$} & \multicolumn{3}{|c|}{ Multivariate analysis } \\
\hline & & OR & $95 \% \mathrm{CI}$ & $\mathrm{p}$ \\
\hline Age & 0.95 & - & - & - \\
\hline Gender & 0.49 & - & - & - \\
\hline IL-10 serum levels & $<10^{-3}$ & 1.16 & $1.08-1.25$ & $<10^{-3}$ \\
\hline Positive-H. pylori serology/UBT & $<10^{-3}$ & 4.60 & $1.40-15.58$ & 0.01 \\
\hline $\mathrm{HBV} / \mathrm{HCV} /$ non cirrhotic alcoholic disease/pancreatic tumour ${ }^{a}$ & 0.02 & 3.51 & $1.49-8.25$ & 0.004 \\
\hline IL-17 serum levels & $<10^{-3}$ & 0.98 & $0.97-0.99$ & 0.01 \\
\hline Positive-H. pylori serology/UBT & $<10^{-3}$ & 3.41 & $1.50-17.30$ & 0.01 \\
\hline $\mathrm{HBV} / \mathrm{HCV} /$ non cirrhotic alcoholic disease/pancreatic tumour ${ }^{a}$ & 0.02 & 5.40 & $2.31-10.58$ & $<10^{-3}$ \\
\hline IFN- $\gamma$ serum levels & $<10^{-3}$ & 0.91 & $0.87-0.95$ & $<10^{-3}$ \\
\hline Positive-H. pylori serology/UBT & $<10^{-3}$ & 4.84 & $1.44-16.13$ & 0.01 \\
\hline $\mathrm{HBV} / \mathrm{HCV} /$ non cirrhotic alcoholic disease/pancreatic tumour ${ }^{a}$ & 0.02 & 4.28 & $2.12-8.68$ & $<10^{-3}$ \\
\hline
\end{tabular}

$a$ : to better fit the models, patients with hepatitis B virus (HBV)/hepatitis C virus (HCV), non cirrhotic alcoholic disease and pancreatic carcinoma were evaluated together. The Hosmer-Lemeshow test showed good fit of the models ( $p \geq 0.42,8 \mathrm{df}, 10$ steps for all). Each cytokine was evaluated in different models because they were highly correlated. Although the number of patients who had used/exposed to drugs was representative, it was not included in the analysis because the drugs had different effects on the liver function; CI: confidence interval; IFN: interferon; IL: interleukin; OR: odds ratio; UBT: urea breath test.

also confirmed recent findings (Lemmers et al. 2009) showing increased IL-17A hepatic levels and Th17 cell numbers associated with the increased severity of liver lesions in patients with alcoholic hepatic disease. Notably, we demonstrated here that serum/liver IL-17A concentrations are very high in patients with autoimmune hepatitis, in accordance with the current data, showing Th17 cells as playing a critical role in autoimmunity (Wong et al. 2008). Thus, in addition to the putative role of IFN- $\gamma$ and IL-17A in the liver immunopathology, our results showed that both cytokines might contribute to the liver defence against microorganisms such as $H$. pylori.

Because $H$. pylori-positive serology/UBT status was independently associated with the presence of $H$. pylori DNA in the liver and the H. pylori strains isolated from the liver had similar characteristics to those isolated from the stomach, we might hypothesise that gastric $H$. pylori has access to the liver by retrograde transfer from the duodenum when the cytokine pattern of the host is more regulatory than proinflammatory. However, it has to be emphasised that the cytokine pattern characterised by high IL-10, low or absent IFN- $\gamma$ and decreased IL-17 levels might be an essential, but not sufficient risk factor for $H$. pylori liver positivity, because this profile was also observed in some gastric $H$. pylori-positive patients who did not have the bacterium in the liver.

Considering that this is an association study, that only DNA instead of viable $H$. pylori was observed in the liver and that no association with cirrhosis was found, one cannot conclude that there is a cause-effect relationship between the presence of $H$. pylori in the liver and risk of hepatic diseases or disease complications. Taking also in account the cytokine profile of the patients, it is tempting to speculate that the presence of the bacterium in the liver is more consequence rather than cause of hepatic diseases.

In conclusion, the host immune response might determine not only the hepatic disease outcome, but also the ability of the liver in clearing certain microorganisms, such as those of the Helicobacter genus as H. pylori.

\section{ACKNOWLEDGEMENTS}

To Dr José Dayrell Andrade, Dr Bruno Squacio Sanchez and Dr Gustavo Martins, for their help in getting liver samples.

\section{REFERENCES}

Algood HM, Cover TL 2006. Helicobacter pylori persistence: an overview of interactions between $H$. pylori and host immune defenses. Clin Microbiol Rev 19: 597-613.

Avenaud P, Marais A, Monteiro L, Le Bail B, Bioulac-Sage P, Balabaud C, Mégraud F 2000. Detection of Helicobacter species in the liver of patients with and without primary liver carcinoma. Cancer 89: 1431-1439.

Caruso R, Pallone F, Monteleone G 2007. Emerging role of IL-23/ IL-17 axis in $H$. pylori-associated pathology. World J Gastroenterol 13: 5547-5551.

D'Elios MM, Manghetti M, De Carli M, Costa F, Baldari CT, Burroni D, Telford JL, Romagnani S, Del Prete G 1997. T helper 1 effector cells specific for Helicobacter pylori in the gastric antrum of patients with peptic ulcer disease. J Immunol 158: 962-967.

Dore MP, Realdi G, Mura D, Graham DY, Sepúlveda AR 2002. Helicobacter infection in patients with HCV-related chronic hepatitis, cirrhosis and hepatocellular carcinoma. Dig Dis Sci 47: 1638-1643.

Fainboim L, Chernavsky A, Paladino N, Flores AC, Arruvito L 2007. Cytokines and chronic liver disease. Cytokine Growth Factor Rev 18: 143-157. 
Fan XG, Peng XN, Huang Y, Yakoob J, Wang ZM, Chen YP 2002. Helicobacter species ribosomal DNA recovered from the liver tissue of Chinese patients with primary hepatocellular carcinoma. Clin Infect Dis 35: 1555-1557.

Lafdil F, Miller AM, Ki SH, Gao B 2010. Th17 cells and their associated cytokines in liver diseases. Cell Mol Immunol 22: 1-5.

Lemmers A, Moreno C, Gustot T, Maréchal R, Degré D, Demetter P, Nadai P, Geerts A, Quertinmont E, Vercruysse V, Le Moine O, Devière J 2009. The interleukin-17 pathway is involved in human alcoholic liver disease. Hepatology 49: 646-657.

Marzio L, Angelucci D, Grossi L, Diodoro MG, Campli ED, Cellini L 1998. Anti-Helicobacter pylori specific antibody immunohistochemistry improves the diagnostic accuracy of Helicobacter pylori in biopsy specimen from patients treated with triple therapy. Am J Gastroenterol 93: 223-226.

Moura SB, Almeida LR, Guerra JB, Rocha GA, Rocha AMC, Melo FF, Corrêa-Oliveira R, Bittencourt P, Carvalho SD, Queiroz DMM 2008. Toll-like receptor (TLR2, TLR4 and TLR5) gene polymorphisms and Helicobacter pylori infection in children with and without duodenal ulcer. Microbes Infect 10: 1477-1483.

Oliveira AG, Rocha GA, Rocha AM, Sanna MG, Moura SB, Dani R, Marinho FP, Moreira LS, Ferrari ML, Castro LP, Queiroz DMM 2006. Isolation of Helicobacter pylori from the intestinal mucosa of patients with Crohn's disease. Helicobacter 11: 2-9.

Pellicano R, Ménard A, Rizzetto M, Mégraud F 2008. Helicobacter species and liver diseases: association or causation? Lancet Infect Dis 8: 254-260.

Queiroz DMM, Santos A, Oliveira AG, Rocha GA, Moura SB, Camargo ERS, Valle PR, Bicalho LAF, Dani R 2001. Isolation of a Helicobacter strain from the human liver. Gastroenterology 121: 1023-1024 (erratum in Gastroenterology 122: 250, 2002).
Rocha GA, Oliveira AM, Queiroz DMM, Mendes EN, Moura SB, Oliveira CA, Ferrari TCA 1998. Serodiagnosis of Helicobacter pylori infection by Cobas Core ELISA in adults from Minas Gerais, Brazil. Braz J Med Biol Res 31: 1263-1268.

Rocha M, Avenaud P, Ménard A, Le Bail B, Balabaud C, Bioulac-Sage P, Queiroz DMM, Mégraud F 2005. Association of Helicobacter species with hepatitis C cirrhosis with or without hepatocellular carcinoma. Gut 54: 396-401.

Sherlock S, Dooley J 2002. Malignant liver tumors. In S Sherlock, J Dooley, Diseases of the liver and biliary system, Blackwell, London, p. 537-554.

Straubinger RK, Greiter A, McDonough SP, Gerold A, Scanziani E, Soldati S, Dailidiene D, Dailide G, Berg DE, Simpson KW 2003. Quantitative evaluation of inflammatory and immune responses in the early stages of chronic Helicobacter pylori infection. Infect Immun 71: 2693-2703.

Verhoef C, Pot RG, de Man RA, Zondervan PE, Kuipers EJ, IJzermans JN, Kusters JG 2003. Detection of identical Helicobacter DNA in the stomach and in the non-cirrhotic liver of patients hepatocellular carcinoma. Eur J Gastroenterol Hepatol 15: 1171-1174.

Wang JT, Lin JT, Sheu JC, Yang JC, Chen DS, Wang TH 1993. Detection of Helicobacter pylori in gastric biopsy tissue by polymerase chain reaction. Eur J Clin Microbiol Infect Dis 12: 367-371.

Wong CK, Lit LCW, Tam LS, Li EKM, Wong PTY, Lam CWK 2008. Hyperproduction of IL-23 and IL-17 in patients with systemic lupus erythematosus: implications for Th17-mediated inflammation in auto-immunity. Clin Immunol 127: 385-393.

Zhang JY, Zhang Z, Lin F, Zou ZS, Xu RN, Jin L, Fu JL, Shi F, Shi M, Wang HF 2010. Interleukin-17-producing CD4 $\left(^{+}\right) \mathrm{T}$ cells increase with severity of liver damage in patients with chronic hepatitis B. Hepatology 51: 81-91. 